\title{
Effects of Biochemical and Molecular Inhibitors of Plant Extracts on Pathogenic Bacteria
}

\author{
Ashwag Al-Zahrani' ${ }^{1}$ Effat Al-Judaibi'2, Hanan Omar ${ }^{2,3}$, Awatif Al-Judaibi² \\ ${ }^{1}$ Department of Food Science, College of Sciences and Arts, Jeddah University, Al-Kamil, KSA \\ ${ }^{2}$ Department of Biological Science, Science Faculty for Girls, King Abdulaziz University, Jeddah, KSA \\ ${ }^{3}$ Department of Botany and Microbiology, Faculty of Science, Tanta University, Tanta, Egypt \\ Email: aamaljudaibi@kau.edu.sa
}

How to cite this paper: Al-Zahrani, A. Al-Judaibi, E., Omar, H. and Al-Judaibi, A. (2017) Effects of Biochemical and Molecular Inhibitors of Plant Extracts on Pathogenic Bacteria. Journal of Biosciences and Medicines, 5, 44-55.

https://doi.org/10.4236/jbm.2017.55005

Received: April 3, 2017

Accepted: May 23, 2017

Published: May 26, 2017

Copyright (C) 2017 by authors and Scientific Research Publishing Inc. This work is licensed under the Creative Commons Attribution International License (CC BY 4.0).

http://creativecommons.org/licenses/by/4.0/

\begin{abstract}
The study aimed to evaluate the effect of the green alga Ulva lactuca and medicinal plant Nigella sativa extract on the activity of Staphylococcus aureus and Pseudomonas aeruginosa. The bacteria were incubated with the crude extracts and extracellular free potassium and phosphorus ions were measured in the medium. The levels of potassium and phosphorous were the maximum in the medium of $S$. aureus treated with $N$. sativa extract. The medium of $P$. aeruginosa incubated with $U$. lactuca extract was found to have the lowest phosphorous and the greatest potassium levels. The highest activity against $P$. aeruginosa was noticed with $U$. lactuca extract, where it caused reduction in the dry weight and glucose consumption of bacteria estimated by $28.41 \%$ and $41.09 \%$, respectively. The antibacterial activity of $N$. sativa extract was the greatest against $S$. aureus and recorded $32.59 \%$ and $39.96 \%$ reduction in the bacterial dry weight and glucose uptake, respectively. Scanning Electron Microscopy study showed morphological changes in the cell wall of treated bacteria. The treatment of bacteria with the tested extract induced gene mutations. The results assessed the possible application of $U$. lactuca and $N$. sativa as a source of pharmacological benefits.
\end{abstract}

\section{Keywords}

Natural Products, Antibacterial Activity, Biochemical Analysis, Molecular Analyses, Morphological Changes

\section{Introduction}

The use of antibiotics has been an effective treatment option for a variety of microbial infections. Antibiotic misuse or overuse has contributed to the creation of a new generation of antibiotic-resistant microorganisms. One important area 
of study is testing the level of susceptibility and drug-resistance in microorganisms to specific antibiotics. The European Centre for Disease Prevention and Control (ECDC) and the Centers for Disease Control and Prevention (CDC) created terminology to define the various levels of the acquired antibiotic resistance profiles in microorganisms: multidrug resistant (MDR) was defined as "acquired non-susceptibility to at least one agent in three or more antibiotics", extremely drug resistant (XDR) was defined as "non-susceptibility to at least one agent in all but two or fewer antimicrobial categories", and pan drug resistant (PDR) was defined as "non-susceptibility to all agents in all antibiotics". The study covered Staphylococcus aureus, Enterococcus spp., Enterobacteriaceae, Pseudomonas aeruginosa and Acinetobacter spp. [1]. Many bacteria strains were identified as MDR, XDR or PDR, including $P$. aeruginosa, Klebsiella pneumoniae, S. aureus and Enterococcus spp., E. coli, and Acinetobacter spp. [2] [3] [4].

The development of new antimicrobial agents required to address the new generation of drug-resistant microorganisms currently on the rise is vital. Microbiota found in malt and marine environments, shows great promise in being potential sources of antimicrobial active compounds.

Several medical research studies have shown some marine algae contain organic compounds that have a broad range of biological activities, including antibacterial, antifungal, antioxidant, antifouling, anti-inflammatory, cytotoxic, anticancer and antimitotic properties [5] [6] [7] [8]. The macroalgae Ulva lactuca has been shown to exhibit antimicrobial activity against gram positive and gram negative bacteria such as $S$. aureus, $S$. epidermidis, $S$. saprophyticus, Streptococcus agalactiae (group B), S. pyogenes, Enterococcus faecalis, Bacillus subtilis, Lactobacillus acidophilus, P. aeruginosa, E. coli, Enterobacter aerogenes, Stenotrophomonas maltophilia, Salmonella typhimurium, Shigella sonnei, Proteus vulgaris and P. mirabilis [9] [10] [11].

Many soil-grown plants, called medicinal plants, have been shown to express bioactive compounds that can act as antimicrobial agents. These secondary metabolites produced by medicinal are an important source for pharmaceutical drugs. In fact, bioactive products derived from medicinal plants are a principal source of pharmaceutical agents used in traditional medicine and work by acting as antimicrobial agents against pathogenic microorganisms [12] [13] [14].

Several plants have been defined as medicinal and have been used for years to treat infectious diseases, such as Thymol sp., Ocimum sp., Oregano sp. and Nigella sp. [15] [16] [17]. Seed extracts and essential oils of Nigella sativa have been used to treat a variety of diseases and are shown to have various pharmacological properties including antimicrobial actions [18] [19]. N. sativa has an inhibitory effect on MRSA, S. aureus, S. epidermidis, E. coli, S. typhi, S. enteritidis, Klebsiella sp. and Enterobacter aerogenes [20] [21].

The present investigation aims to study the influence of methanol extract of green alga Ulva lactuca and medicinal plant Nigella sativa on the activity and molecular genetics of pathogenic Gram positive cocci Staphylococcus aureus and the Gram negative bacilli Pseudomonas aeruginosa. 


\section{Materials and Methods}

\subsection{Extract Preparation}

The green alga Ulva lactuca and the seeds of medicinal plant Nigella sativa were collected from Jeddah, Saudi Arabia. The samples were cleaned, washed with distilled water, dried at $40^{\circ} \mathrm{C}$ and powdered in a mixer grinder. The powdered samples were extracted by soaking in methanol $(1: 10, \mathrm{w} / \mathrm{v})$ for several times at room temperature. The deposits were then used as crude extracts. The extracts were dried under vacuum pressure at $40^{\circ} \mathrm{C}$ [22] [23]. The crude extract was stored at $-20^{\circ} \mathrm{C}$ until required.

\subsection{Test Bacteria}

The tested bacteria Staphylococcus aureus and Pseudomonas aeruginosa were isolated and identified at King Abdulaziz University Hospital, Jeddah, Saudi Arabia. The isolates were grown on Mueller-Hinton agar (OXOID CM 337) [24] [25] [26].

\subsection{Biochemical Analyses}

The pathogenic bacteria $\left(1 \times 10^{5} \mathrm{CFU} \cdot \mathrm{ml}^{-1}\right)$ were incubated with $100 \mu \mathrm{l}$ crude extracts $\left(100 \mathrm{mg} \cdot \mathrm{ml}^{-1}\right)$ at different intervals $(20,40,60$ and $80 \mathrm{mins})$ in Mueller-Hinton broth at $37^{\circ} \mathrm{C}$ [27]. The extracellular potassium and phosphorus concentrations were estimated by a photometric procedure using EasyRA Medica and COBAS ${ }^{\circledR}$ INTEGRA 400 plus, respectively. The results were expressed as the value of extracellular free potassium and phosphorus ions in the medium $\left(\mathrm{mmol} \cdot \mathrm{L}^{-1}\right)$.

The effect of different concentrations (50 and $100 \mu \mathrm{l})$ of crude extract (100 $\mathrm{mg} \cdot \mathrm{ml}^{-1}$ ) on glucose uptake and dry weight of bacteria was investigated according to [28]. The pathogenic bacteria $\left(1 \times 10^{5} \mathrm{CFU} \cdot \mathrm{ml}^{-1}\right)$ were inoculated into Mueller-Hinton broth and incubated with the different concentrations of extract on a shaker $(180 \mathrm{rpm})$ at $37^{\circ} \mathrm{C}$ for $24 \mathrm{~h}$. Samples were then centrifuged at 10,000 rpm for 10 mins. Glucose uptake was measured in the suspension solution by using COBAS ${ }^{\circledast}$ INTEGRA 400 plus. The pellets were washed triple with distilled water and centrifuged at $10,000 \mathrm{rpm}$ for $10 \mathrm{mins}$ and then dried at $80^{\circ} \mathrm{C}$. Bacterial growth was measured as dry weight. Each treatment was performed in triplicate.

\subsection{Molecular Analyses}

The effect of $U$. lactuca and $N$. sativa extract on the genetic material of pathogenic bacteria was studied as recommended by [29]. The bacterial DNA was extracted with methanol using Qiagen DNA extraction kit (Molecular sequencing of the mecA gene in $S$. aureus and acsA gene in P. aeruginosa) and the following PCR primers:

\section{$S$. aureus}

MR1 TAGAAATGACTGAACGTCCG; 


\section{MR2 TTGCGATCAAATGTTACCGTAG; \\ MR3 AAAATCGATGGTAAAGGTTGGC; \\ MR4 AGTTCTGCAGTACCGGATTTTGC. \\ $P$. aeruginosa \\ acsA-F GCCACACCTACATCGTCTAT; \\ acsA-R AGGTTGCCGAGGTTGTCCAC.}

The DNA was sequenced by Macrogene (https://www.macrogenusa.com/) and analyzed by BLAST software (http://blast.ncbi.nlm.nih.gov/Blast.cgi).

\subsection{Scanning Electron Microscopy (SEM) Analyses}

A thin film of treated bacterial cells with $50 \mu \mathrm{l}$ of $U$. lactuca and $N$. sativa extracts (100 mg. $\mathrm{ml}^{-1}$ ) were smeared on a silver stub for analysis by SEM [30] [31]. The samples were coated with gold by cathodic spraying (Polaron gold) and then dried under a mercury lamp for 5 mins. The morphology of $S$. aureus and $P$. aeruginosa were observed by using scanning electron microscope at Nano Center of KAU (JEOL, JSM-7600F 450).

\subsection{Statistical Analysis}

The results were analyzed by paired-samples $t$-test using the IBM SPSS 20 statistical software to compare the mean values of each treatment. The results are expressed as the means \pm SD. Probability levels of less than 0.01 were considered highly significant.

\section{Results}

\subsection{Biochemical Analyses}

The treatment of $S$. aureus and $P$. aeruginosa with $100 \mu \mathrm{l} U$. lactuca and $N$. sativa crude extract $\left(100 \mathrm{mg} \cdot \mathrm{ml}^{-1}\right)$ showed an increase in the leakage of potassium and phosphorus ions with increasing time of incubation (20,40, 60 and 80 minutes). The levels of potassium $68.54 \%$ and phosphorus $38.24 \%$ recorded highly significant increase $(\mathrm{P}<0.01)$ in the bacterial medium of $S$. aureus treated with $N$. sativa extract (Figure 1). At the same time, the treatment of $P$. aeruginosa with $U$. lactuca extract (Figure 2) induced the presence of maximum level of potassium 36.05\% and the minimum value of phosphorous $13.10 \%$ as compared with $N$. sativa extract $27.29 \%$ and $18.97 \%$, respectively. $S$. aureus was the most sensitive to the extract of $N$. sativa with respect to the decrease in the ability to regulate cell permeability, whereas $U$. lactuca extract was more effective against $P$. aeruginosa.

Glucose uptake is reflected in the bacterial biomass that determined as dry weight in the untreated cells and directly contrasted with the biomass growth weight analyzed during the incubation period with $U$. lactuca and $N$. sativa extracts. The influence of 50 and $100 \mu \mathrm{l}$ tested extract on the bacterial metabolism expressed as glucose uptake is shown in Table 1. As the concentration of $U$. lactuca and $N$. sativa treated extracts increased, glucose uptake was found to be decreased with $S$. aureus $53.00 \%$ and $39.96 \%$, respectively and $P$. aeruginosa 
$41.09 \%$ and $44.74 \%$, respectively. Therefore, a decrease in glucose uptake was reflected in the less dry weight of treated bacteria with tested extracts. The results in Table 2 clarified that the lowest dry weight of $S$. aureus 32.59\% was observed when treated with $N$. sativa extract. However, $P$. aeruginosa showed the minimum dry weight $28.41 \%$ during the incubation with $U$. lactuca extract.

The results of an SEM study showed the changes in the bacterial morphology and structure in response to the methanol extracts of $U$. lactuca (Figure 3 ) and $N$. sativa (Figure 4). The treatment of bacteria with the extract of $U$. lactuca and $N$. sativa resulted in the formation of cavities in cells as well as shrinkage, aggregation, rupture, and partial deformation of the cell wall.

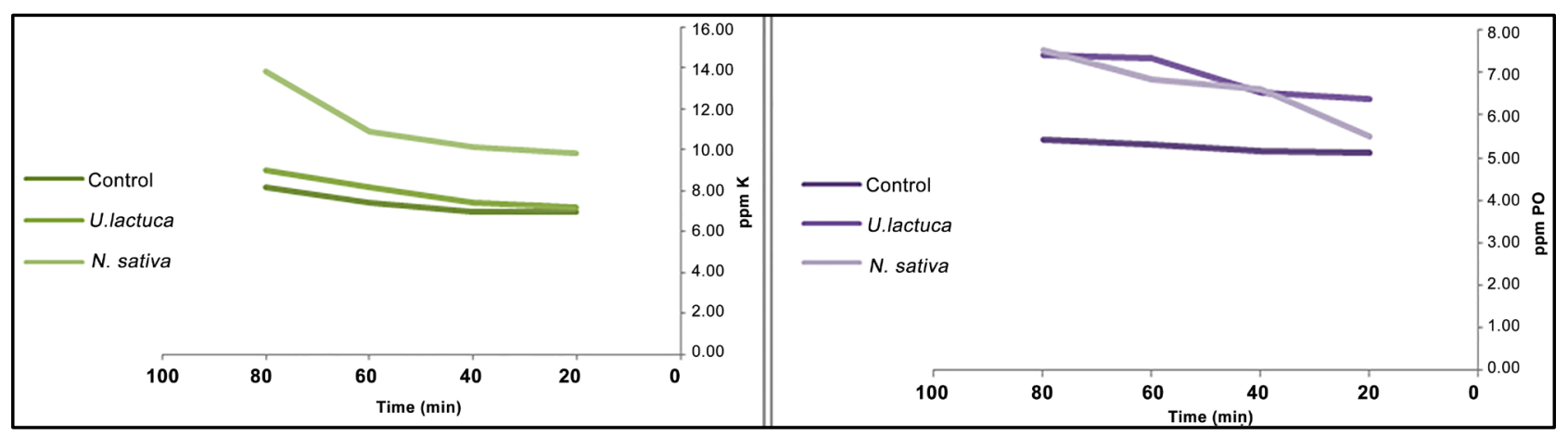

(A)

(B)

Figure 1. Potassium (A) and phosphorus (B) leakage of $S$. aureus treated with $100 \mu$ of U. lactuca and N. sativa extract after 20, 40, 60 and 80 minutes of incubation.

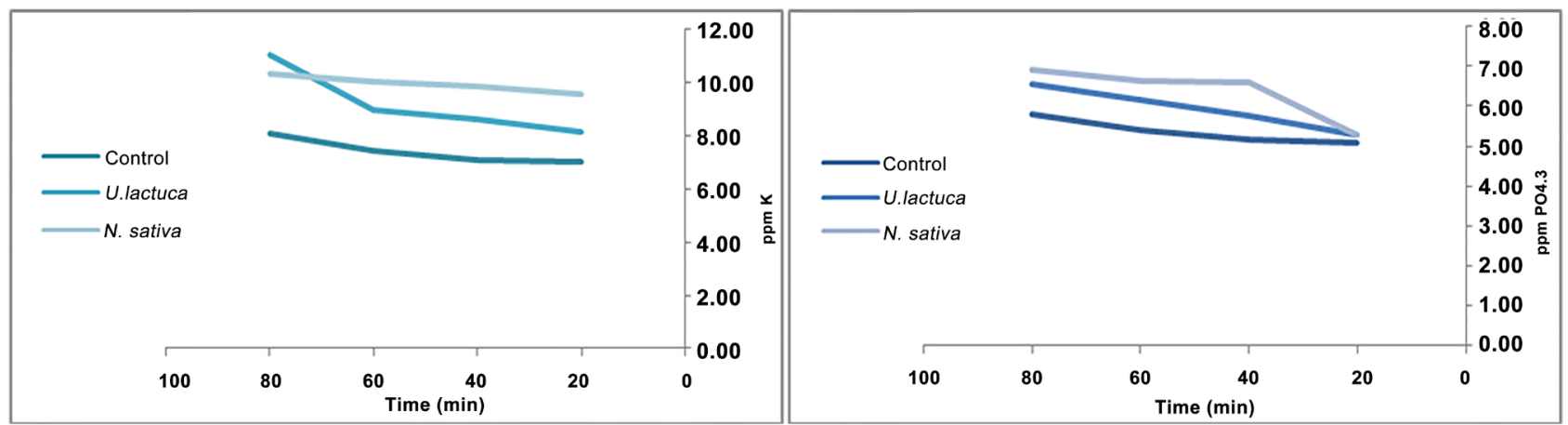

(A)

(B)

Figure 2. Potassium (A) and phosphorus (B) leakage of $P$. aeruginosa treated with $100 \mu \mathrm{l}$ of U. lactuca and $N$. sativa extract after $20,40,60$ and 80 minutes of incubation.

Table 1. Glucose uptake ((mg DL-1) of $S$. aureus and $P$. aeruginosa treated with 50 and $100 \mu \mathrm{l}$. lactuca and $N$. sativa extract after 24 hours of incubation (Mean $\pm \mathrm{SD}$ ).

\begin{tabular}{cccccc}
\hline \multirow{2}{*}{ Bacteria } & Control & \multicolumn{2}{c}{ U. lactuca } & \multicolumn{2}{c}{ N. sativa } \\
\cline { 3 - 6 } & untreated cells & $50 \mu \mathrm{l}$ & $100 \mu \mathrm{l}$ & $50 \mu \mathrm{l}$ & $100 \mu \mathrm{l}$ \\
\hline S. aureus & $4.83 \pm 0.011$ & $3.57 \pm 0.006^{* *}$ & $2.27 \pm 0.021^{* *}$ & $4.32 \pm 0.010^{* *}$ & $2.90 \pm 0.006^{* *}$ \\
P. aeruginosa & $4.94 \pm 0.016$ & $3.97 \pm 0.006^{* *}$ & $2.91 \pm 0.045^{* *}$ & $4.00 \pm 0.285^{*}$ & $2.73 \pm 0.006^{* *}$
\end{tabular}


Table 2. Dry weight (mg) of $S$. aureus and P. aeruginosa treated with 50 and $100 \mu \mathrm{l} U$. lactuca and $N$. sativa extract after 24 hours of incubation (Mean \pm SD).

\begin{tabular}{cccccc}
\hline \multirow{2}{*}{ Bacteria } & Control & \multicolumn{2}{c}{ U. lactuca } & \multicolumn{2}{c}{ N. sativa } \\
\cline { 3 - 6 } & $\begin{array}{c}\text { untreated } \\
\text { cells' }\end{array}$ & $50 \mu \mathrm{l}$ & $100 \mu \mathrm{l}$ & $50 \mu \mathrm{l}$ & $100 \mu \mathrm{l}$ \\
\hline S. aureus & $31.30 \pm 1.54$ & $26.30 \pm 0.46^{* *}$ & $19.50 \pm 0.46^{* *}$ & $22.50 \pm 1.00^{* *}$ & $21.10 \pm 0.63^{* *}$ \\
P. aeruginosa & $35.90 \pm 1.79$ & $26.80 \pm 0.55^{* *}$ & $25.70 \pm 0.05^{* *}$ & $14.70 \pm 0.05^{* *}$ & $14.60 \pm 0.41^{* *}$ \\
\hline
\end{tabular}
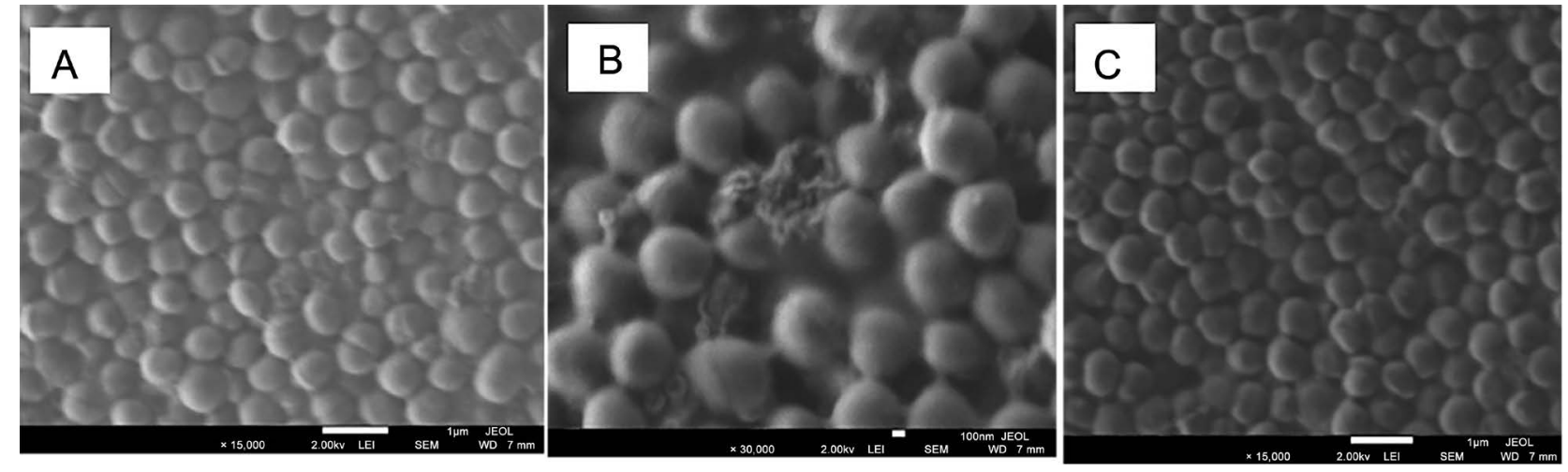

Figure 3. SEM showed the effect of $U$. lactuca (A) and N. sativa (B) extracts on the cell wall of $S$. aureus, compared to control (C).
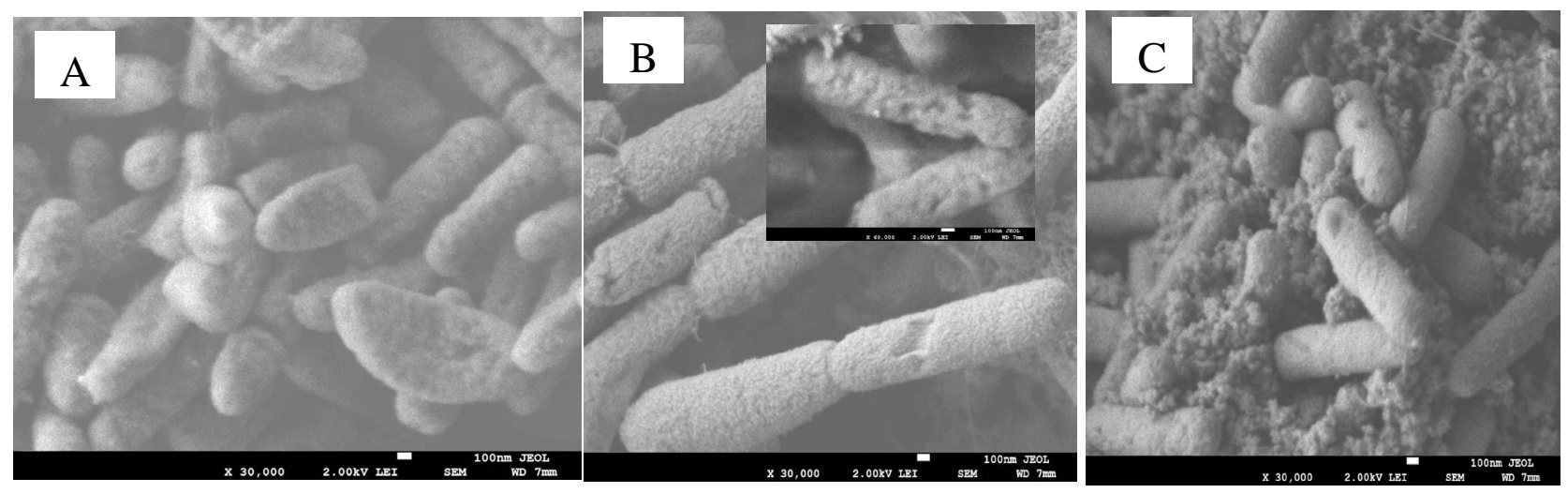

Figure 4. SEM showed the effect of $U$. lactuca (A) and $N$. sativa (B) extracts on the cell wall of $P$. aeruginosa, compared to control (C).

\subsection{Molecular Analyses}

The molecular investigation of the $S$. aureus antibiotics resistant gene mecA, and $P$. aeruginosa Acetyl coenzyme A synthetase gene acsA, are found in Figure 5 and Figure 6. Bacteria treated with $U$. lactuca and $N$. sativa extract showed changes in the gene sequence of the selected microorganism, compared with the untreated sample.

As shown in Figure 5 for $S$. aureus, five mismatches and two gaps were observed after treatment with $N$. sativa, and two mismatches and two gaps were noticed after treatment with $U$. lactuca. The primer used in this sequence was Mr3. Two gaps occurred in the treatment with the extract of $N$. sativa in the bases 26 and 432, whereas no gaps occurred in the gene after the treatment with $U$. lactuca extract for Mr4, there were 4 mismatches after treatment with $N$. sa- 
tiva in the bases 165, 186 and 199 after the treatment with $N$. sativa extract. Furthermore, there was one mismatch in base 501 and one gap in base 504 after treatment with $U$. lactuca extract.

Query 14 GgGtgGtTANNACGTTACAAGATATGAAGTGGTAAATGGTAATATCGACTTAAAACAAGC 7

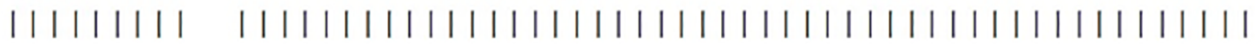
Sbjct 15 GGGTGGTTA-CACGTTACAAGATATGAAGTGGTAAATGGTAATATCGACTTAAAACAAGC

Mr3 S. aureus treated with $N$. sativa

Query 494 CCGGTACTGACANAACTa 511

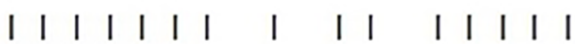

Sbjct 494 CCGGTACGG-CAGAACTA 510

Mr3 S. Areas treated with N. sativa

Query 505 ANAACTaaa 513

||||||||

Sbjct 505 AGAACTAAA 513

Mr3 S. aureus treated with $U$. lactuca

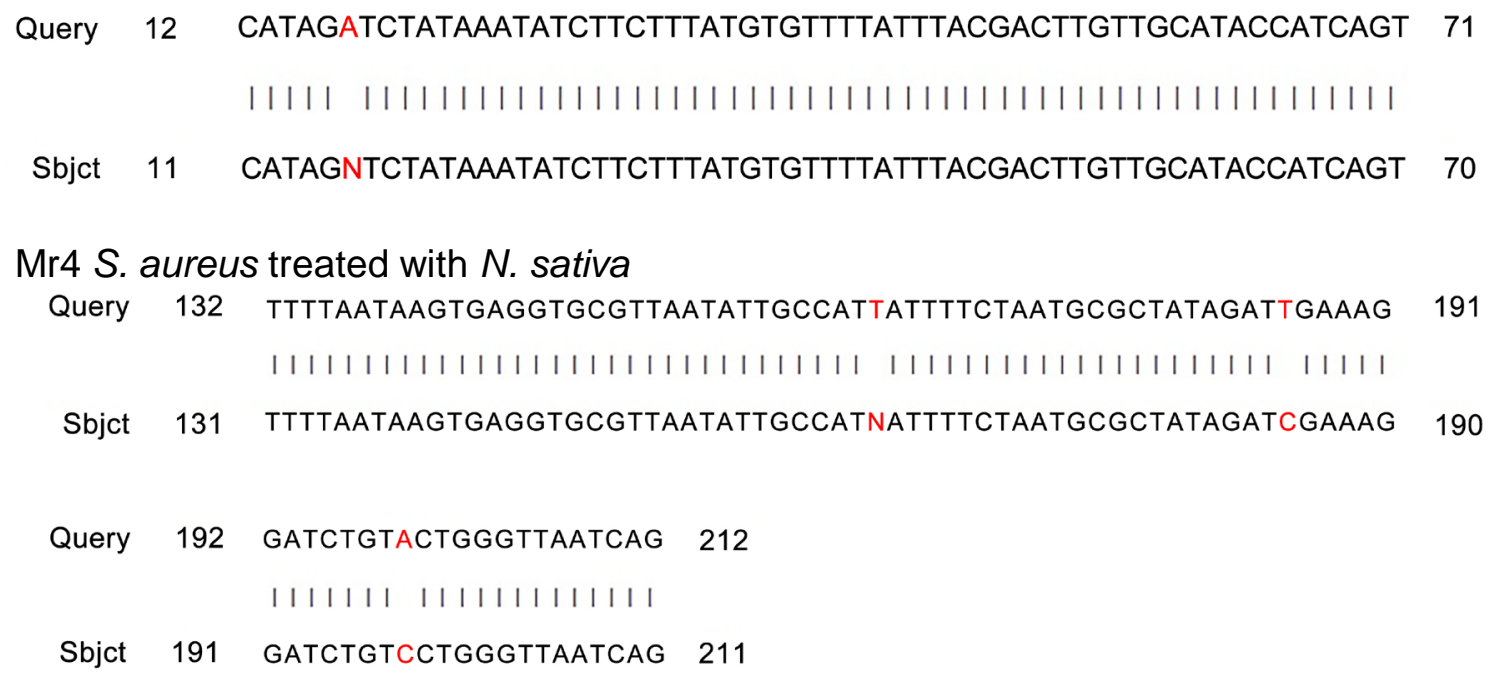

Mr4 S. aureus treated with $N$. sativa

$\begin{array}{llll}\text { Query } & 499 & \text { CATTCCGATTTTnaal } & 514 \\ & & \text { |। |। |। |। | |। } & \\ \text { Sbjct } & 499 & \text { CANTC-GATTTT -AAA } & 512\end{array}$

Mr4 S. aureus treated with U. lactuca

Figure 5. S. aureus $\mathrm{Mr} 3$ and Mr4 gene detection after treatment with $100 \mu \mathrm{l}$ of $U$. lactuca and $N$. sativa extracts. 
F P. aeruginosa treated with $N$. sativa

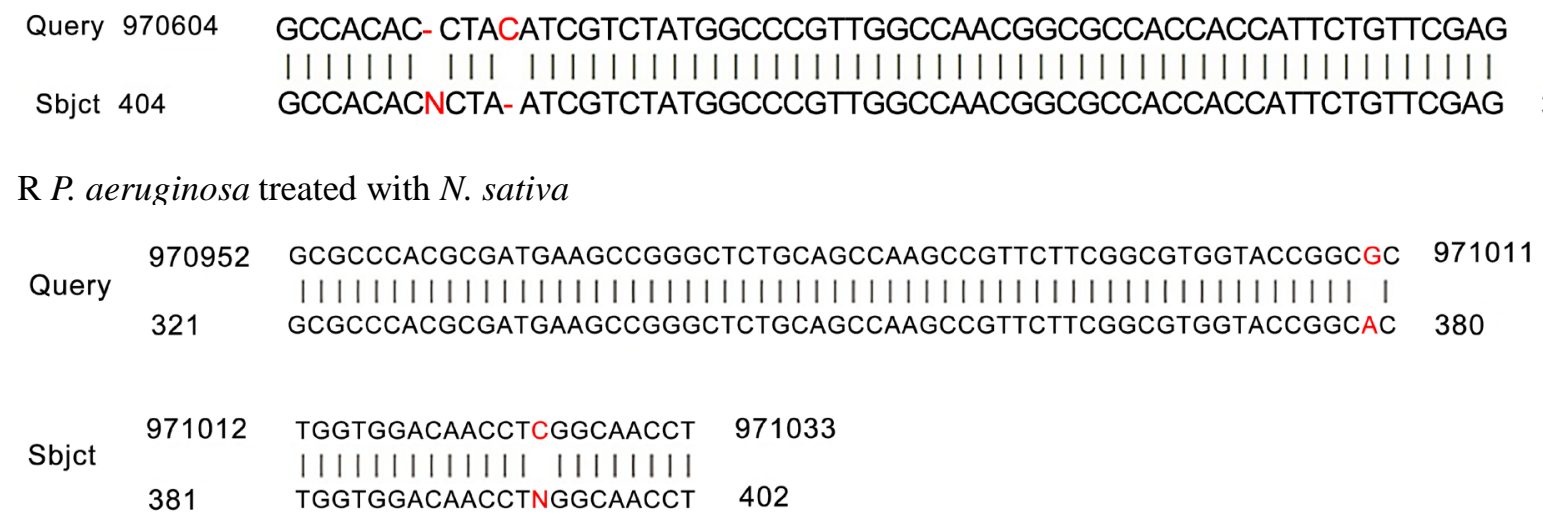

R P. aeruginosa treated with $N$. sativa

\begin{tabular}{|c|c|c|c|c|}
\hline Query & $\begin{array}{l}970952 \\
321\end{array}$ & $\begin{array}{l}\text { GCGCCCACGCGATGAAGCCGGG } \\
|||||||||||||||||||||||| \\
\text { GCGCCCACGCGATGAAGCCGGGC }\end{array}$ & 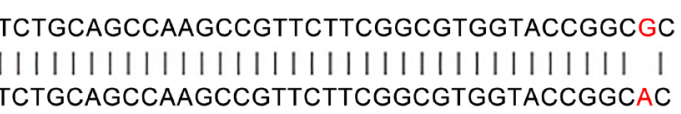 & 971011 \\
\hline Sbjct & $\begin{array}{l}971012 \\
381\end{array}$ & $\begin{array}{l}\text { TGGTGGACAACCTCGGCAACCT } \\
|||||||||||||||||||| \mid \\
\text { TGGTGGACAACCTNGGCAACCT }\end{array}$ & $\begin{array}{l}971033 \\
402\end{array}$ & \\
\hline
\end{tabular}

F P. aeruginosa treated with $U$. lactuca

Query 970604

Sbjct 405

R P. aeruginosa treated with $U$. lactuca

Figure 6. P. aeruginosa $\mathrm{F}$ and $\mathrm{R}$ in ascA gene detection after treatment with $100 \mu \mathrm{l}$ of $U$. lactuca and $N$. sativa extracts.

Figure 6 showed the results of $P$. aeruginosa gene acsA sequence, which included one mismatch in the base 379 for the primer acsA F after treatment with $N$. sativa extract and 2 gaps in the bases 379 and 393 for the primer acsA R, compared with the untreated cells. The results show two mismatches in the bases 394 and 379 and two unread bases for bases 394 and 395 for the primer acsA F and one gap in the base 398 for the primer acsA R after treatment with the extract of $U$. lactuca.

\section{Discussion}

Antimicrobial agents can target several parts and processes of a microbe cell, including the cell wall, the cytoplasmic membrane, protein and enzyme production, DNA replication and the DNA genetic code [30] [31]. These alterations are caused by active compounds in the extracts of these medicinal plants, which have been shown to contain bioactive components that act as highly effective antimicrobial agents against microbial infections such as quinine, tannins, terpenoids, sterols, alkaloids and flavonoids [32] [33] [34].

Several studies that analyzed extracts of medicinal plants such as Rhamnus globosa, Ocimum basilicum, Tecoma stans, Coleus forskohlii, Phoenix dactylifera, N. sativa, Elettaria cardamomum, Lawsonia inermis, Embelia ribes and Santalum album have shown that they contain active compounds that can di- 
rectly inhibit the growth activity of Gram negative and positive bacteria including Bacillus subtilis, B. cereus, S. aureus, S. aureus MRSA Corynebacterium bovis, Pseudomonas aeruginosa, Pasteurella multocida and E. coli [35] [36] [37].

It has been shown that $N$. sativa L. has several pharmacological effects that have been attributed to the active components in the seed extracts including thymoquinone, thymohydroquinone, dithymoquinone, thymol, carvacrol, nigellicine, nigellimine-x-oxide, nigellidine and alpha-hederin [38] [39]. Furthermore, the GC-MS analysis of $U$. lactuca extracts reveal the existence of phytochemical products such as phytol, hexadecanoic acid, ethyl ester and (E)-9-octadecenoic acid ethyl ester, thymoquinone, $\alpha$-thujene, thymohydroquinone, $\mathrm{p}$-cymene, dehydro-sabina ketone, carvacrol and longifolene [40]. The antimicrobial activity of $U$. lactuca has been verified by the studies with several pathogenic microorganisms including $K$. pneumonia, E. coli, E. aerogens, $P$. aeruginosa, $M$. luteus, E. faecalis, $S$. aureus, $S$. aureus, MRSA, S. faecalis and B. subtilis [41] [42] [43]. Moreover, the increase in potassium and phosphorus leakage returned to the effect of the extract on the permeability of the cytoplasmic membrane, as verified by SEM. In addition, the rate of gene mutation was shown to be higher in tested bacteria treated with $U$. lactuca and $N$. sativa extract [5] [27] [44] [45] [46].

\section{Conclusion}

The present study concluded that the extract of the green alga, $U$. lactuca and the seeds of medicinal plant, $N$. sativa can be used as a source for antibacterial agent. Further works should be done for isolation and characterization of the active compounds.

\section{References}

[1] Magiorakos, A.-P., Srinivasan, A., Carey, R.B., Carmeli, Y., Falagas, M.E., Giske, C.G., Harbarth, S., Hindler, J.F., Kahlmeter, G., Olsson-Liljequist, B., Paterson, D.L., Rice, L.B., Stelling, J., Struelens, M.J., Vatopoulos, A., Weber, J.T. and Monnet, D.L. (2012) Multidrug-Resistant, Extensively Drug-Resistant and Pandrug-Resistant Bacteria: An International Expert Proposal for Interim Standard Definitions for Acquired Resistance. Clinical Microbiology and Infection, 18, 268-281. https://doi.org/10.1111/j.1469-0691.2011.03570.x

[2] Pontikis, K., Karaiskos, I., Bastani, S., Dimopoulos, G., Kalogirou, M., Katsiari, M., Oikonomou, A., Poulakou, G., Roilides, E. and Giamarellou, H. (2014) Outcomes of Critically Ill Intensive Care Unit Patients Treated with Fosfomycin for Infections Due to Pandrug-Resistant and Extensively Drug-Resistant Carbapenemase-Producing Gram-Negative Bacteria. Journal of Antimicrobial Agents, 43, 52-59.

[3] Giamarellou, H., Galani, L., Baziaka, F. and Karaiskos, I. (2013) Effectiveness of a Double-Carbapenem Regimen for Infections in Humans Due to CarbapenemaseProducing Pandrug-Resistant Klebsiella pneumoniae. Antimicrobial Agents and Chemotherapy, 5, 2388-2390. https://doi.org/10.1128/AAC.02399-12

[4] Theuretzbache, U. (2013) Global Antibacterial Resistance: The Never-Ending Story. Journal of Global Antimicrobial Resistance, 1, 63-69.

[5] Al-Judaibi, A. (2014) Antibacterial Effects of Extracts of Two Types of Red Sea Al- 
gae. Journal of Biosciences and Medicines, 2, 74-82.

https://doi.org/10.4236/jbm.2014.22012

[6] Jebasingh, S.E.J., Rajesh, R.P. and Lakshmikandan, M. (2011) Antibacterial Activity of Seaweed Ulva lactuca Against Fish Pathogens Isolated from Marine Fish Katsuwonus pelamis. International Journal of Pharmacy \& Technology, 3, 2306-2314.

[7] Demirel, Z., Yilmaz-Koz, F.F., Karabay-Yavasoglu, U., Ozdemir, G. and Sukatar, A. (2009) Antimicrobial and Antioxidant Activity of Brown Algae from the Aegean Sea. Journal of the Serbian Chemical Society, 74, 619-628. https://doi.org/10.2298/JSC0906619D

[8] Blunt, J.W., Copp, B.R., Keyzers, R.A., Munroa, M.H.G. and Prinsep, M.R. (2014) Marine Natural Products. Natural Product Reports, 31, 160-258. https://doi.org/10.1039/c3np70117d

[9] Zbakh, H., Chiheb, H., Bouziane, H., Sánchez, V.M. and Riadi, H. (2012) Antibacterial Activity of Benthic Marine Algae Extracts from the Mediterranean Coast of Morocco. Journal of Microbiology, 2, 219-228.

[10] Pushparaj, A., Raubbin, R.S. and Balasankar, T. (2014) Antibacterial Activity of Kappaphycus alvarezii and Ulva lactuca Extracts against Human Pathogenic Bacteria. International Journal of Current Microbiology and Applied Science, 3, 432-436.

[11] Al-Zahrani, A., Al-Haj, N., Omer, H. and Al-Judaibi, A. (2014) Impact of Extracts of Marine Macroalgae on Multidrug-Resistant Bacteria. Journal of Microbiology Research, 4, 18-24.

[12] Ibrahim, M.B. (1997) Anti-Microbial Effects of Extract Leaf, Stem and Root Bark of Anogeissus leiocarpus on $S$. aureus, $S$. pyogenes, E. coli and Proteus vulgaris. Journal of Pharmaceutical Development, 2, 20-30.

[13] Ogundipe, O., Akinbiyi, O. and Moody, J.O. (1998) Antibacterial Activities of Essential Ornamental Plants. Nigerian Journal of Natural Products and Medicine, 2, 46-47. https://doi.org/10.4314/njnpm.v2i1.11783

[14] Abdul, H., Saleem, S., Chaudhary, S., Barkaat, M. and Arshad, M.U. (2008) Antibacterial Activity of Nigella sativa against Clinical Isolates of Methicillin Resistant Staphyloccocus aureus. Journal of Ayub Medical College Abbottabad, 20, 72-74.

[15] Sundaram, S., Purwar, S., Singh, S.K. and Dwivedi, P. (2014) Diversity among 20 Accession of Three Germplasm of the Medicinal Plant, Ocimum (O. gratissimum, $O$. sanctum and $O$. basilicum, Lamiaceae). Journal of Medicinal Plant Research, 8 , 640-645. https://doi.org/10.5897/JMPR12.1188

[16] Akthar, M.S., Degaga, B. and Azam, T. (2014) Antimicrobial Activity of Essential Oils Extracted from Medicinal Plants against the Pathogenic Microorganisms: A Review. Issues in Biological Sciences and Pharmaceutical Research, 2, 1-7.

[17] Witkowska, A.M., Hickey, D.K. and Wilkinson, M.G. (2014) Effect of Variation in Food Components and Composition on the Antimicrobial Activity of Oregano and Clove Essential Oils in Broth and in a Reformulated Reduced Salt Vegetable Soup Product. Journal of Food Research, 3, 92-106. https://doi.org/10.5539/jfr.v3n6p92

[18] Kazemi, M. (2014) Phytochemical Composition, Antioxidant, Anti-Inflammatory and Antimicrobial Activity of Nigella sativa L. Essential Oil. Journal of Essential Oil Bearing Plants, 17, 1002-1011. https://doi.org/10.1080/0972060X.2014.914857

[19] Vieira, M.L.A., Johann, S., Hughes, F.M., Rosa, C.A. and Rosa, L.H. (2014) The Diversity and Antimicrobial Activity of Endophytic Fungi Associated with Medicinal Plant Baccharis trimera (Asteraceae) from the Brazilian savannah. Canadian Journal of Microbiology, 60, 847-856. https://doi.org/10.1139/cjm-2014-0449

[20] Abdaslam, S.A., Hassan, M.A., Kaheel, H.H., Abobaker, T.M., Alnourain, T.H., 
Hamdan, H.A., Shankar, S.G. and Thambirajah, J.J. (2014) Isolation of Escherichia coli O157 and Other Food Borne Pathogens from Meat Products and Their Susceptibility to Different Antimicrobial Agents. Current Research in Microbiology and Biotechnology, 2, 391-397.

[21] Kmlnd, A. and Ahmad, I.Z. (2014) Alteraion Atbaceril Potenial of Nigela stiva L. Se during Different Phase of Germination. International Journal of Current Microbiology and Applied Science, 3, 268-282.

[22] Vijayakumar, M., Priya, K., Nancy, F.T., Noorlidah, A. and Ahmed, A.B.A. (2013) Biosynthesis, Characterization and Anti-Bacterial Effect of Plant Mediated Silver Nanoparticles Using Artemisia nilagirica. Industrial Crops and Products, 41, 235 240.

[23] Ranjan, P., Das, M.P., Kumar, M.S., Anbarasi, P., Sindhu, S., Sagadevan, E. and Arumugam, P. (2013) Green Synthesis and Characterization of Silver Nanoparticles from Nigella sativa and Its Application against UTI Causing Bacteria.

[24] CLSI (2012) Performance Standards for Antimicrobial Disk Susceptibility Tests; Approved Standard-Eleventh Edition. CLSI Document M02-A11. Clinical and Laboratory Standards Institute, Wayne, 32(1).

[25] CLSI (2007) Performance Standards for Antimicrobial Susceptibility Testing; Seventeenth Information Supplement. CLSI Document M100-S17 (M2-A7 and M7A7), Clinical and laboratory Standards institute, Wayne, 27(1).

[26] Joshua, M. and Takudzwa, M. (2013) Antibacterial Properties of Mangifera Indica on staphylococcus aureus. African Journal of Clinical and Experimental Microbiology, 14, 62-74.

[27] Lambert, R.J.W., Skandamis, P.N., Coote, P.J. and Nychas, G.-J.E. (2001) A Study of the Minimum Inhibitory Concentration and Mode of Action of Oregano Essential Oil, Thymol and Carvacrol. Journal of Applied Microbiology, 91, 453-462. https://doi.org/10.1046/j.1365-2672.2001.01428.x

[28] Madigan, M.T., Martinko, J.M. and Parker, J. (1997) Brock Biology of Microorganisms. 8th Edition, Prentice Hall International, Inc., New York.

[29] Karthy, E.S., Ranjitha, P. and Mohankumar, A. (2009) Antimicrobial Potential of Plant Seed Extracts against Multidrug Resistant Methicillin Resistant Staphylococcus aureus (MDR-MRSA). International Journal of Biology, 1, 34. https://doi.org/10.5539/ijb.v1n1p34

[30] Walsh, C. (2003) Antibiotics: Actions, Origins, Resistance. American Society for Microbiology (ASM) Application. https://doi.org/10.1128/9781555817886

[31] Breukink, E. and de Kruijff, B. (2006) Lipid II as a Target for Antibiotics. Nature Reviews Drug Discovery, 5, 321-323. https://doi.org/10.1038/nrd2004

[32] Patel, J.P., Gami, B. and Patel, K. (2010) Evaluation of in Vitro Schizonticidal Properties of Acetone Extract of Some Indian Medicinal Plants. Advances in Biological Research, 4, 253-258.

[33] George, D.M., Alexandru, M.G., Keng-Shiang, H., Ludovic, E.B. and Cornelia, B. (2015) Prevention of Microbial Communities: Novel Approaches Based Natural Products. Current Pharmaceutical Biotechnology, 16, 94-111. https://doi.org/10.2174/138920101602150112145916

[34] Al-Judaibi, A. and Al-Yousef, F. (2013) Effect of Natural Products from Plant Extracts on Gram-Positive Cocci. World Academy of Science, Engineering and Technology, 83, 315-319.

[35] Al-Judaibi, A., Al-Zahrani, A., Altammar, K.A., Ismail, S.B. and Darweesh, N.T. (2014) Comparative Study of Antibacterial Activity of Plant Extracts from Several 
Regions of Asia. American Journal of Pharmacology and Toxicology, 9, 139-147. https://doi.org/10.3844/ajptsp.2014.139.147

[36] Singh, S., Das, S.S., Singh, G., Schuff, C., de Lampasona, M.P. and Catalán, C.A.N. (2014) Composition, in Vitro Antioxidant and Antimicrobial Activities of Essential Oil and Oleoresins Obtained from Black Cumin Seeds (Nigella sativa L.). BioMed Research International, 2014, Article ID: 918209. https://doi.org/10.1155/2014/918209

[37] Hussain, T., Arshad, M., Khan, S., Sattar, H. and Qureshi, M.S. (2011) In Vitro Screening of Methanol Plant Extracts for their Antibacterial Activity. Pakistan Journal of Botany, 43, 531-538.

[38] Haloci, E., Manfredini, S., Toska, V., Vertuani, S., Ziosi, P., Topi, I. and Kolani, H. (2012) Antibacterial and Antifungal Activity Assessment of Nigella Sativa Essential Oils. International Scholarly and Scientific Research \& Innovation, 6, 1081-1083.

[39] Özmen, A., Basbülbül, G. and Aydin, T. (2007) Antimitotic and Antibacterial Effects of the Nigella sativa L. Seed. Caryologia, 60, 270-272. https://doi.org/10.1080/00087114.2007.10797947

[40] Johnson, B.M., Raja, D.P., Arockiaraj, A.A. and Vinnarasi, J. (2014) Chemical Constituents and Their Biological Activity of Ulva lactuca LINN. International Journal of Pharmaceutics and Drug Analysis, 2, 595-600.

[41] Kandhasamy, M. and Arunachalam, K.D. (2008) Evaluation of in Vitro Antibacterial Property of Seaweeds of Southeast Coast of India. African Journal of Biotechnology, 7, 1958-1961. https://doi.org/10.5897/AJB08.120

[42] Kim, I.H., Lee, D.-G., Lee, S.H., Ha, J.-M., Ha, B.-J., Kim, S.-K. and Lee, J.-H. (2007) Antibacterial Activity of Ulva lactucaagainst Methicillin-Resistant Staphylococcus aureus (MRSA). Biotechnology and Bioprocess Engineering, 12, 579-582. https://doi.org/10.1007/BF02931358

[43] Chandrasekaran, M., Venkatesalu, V. and Raj, G.A. (2014) Antibacterial Activity of Selected Marine Macro Algae against Vancomycin Resistant Enterococcus faecalis. Journal of Coastal Life Medicine, 2, 940-946.

[44] Soberón, J.R., Sgariglia, M.A., Dip Maderuelo, M.R., Andina, M.L., Sampietro, D.A. and Vattuone, M.A. (2014) Antibacterial Activities of Ligaria cuneifolia and Jodina rhombifolia Leaf Extracts against Phytopathogenic and Clinical Bacteria. Journal of Bioscience and Bioengineering, 118, 599-605.

[45] Sanadgol, N. (2014) Methicillin-Resistance Staphylococcus aureus in Southeast Iran: Herbal Control and Detection Methods Comparison. Journal of Medical Science, 14, 123-129. https://doi.org/10.3923/jms.2014.123.129

[46] Mumy, K.L. and Findlay, R.H. (2004) Convenient Determination of DNA Extraction Efficiency Using an External DNA Recovery Standard and Quantitative-Competitive PCR. Journal of Microbiological Methods, 57, 259-268. 
Submit or recommend next manuscript to SCIRP and we will provide best service for you:

Accepting pre-submission inquiries through Email, Facebook, LinkedIn, Twitter, etc. A wide selection of journals (inclusive of 9 subjects, more than 200 journals)

Providing 24-hour high-quality service

User-friendly online submission system

Fair and swift peer-review system

Efficient typesetting and proofreading procedure

Display of the result of downloads and visits, as well as the number of cited articles Maximum dissemination of your research work

Submit your manuscript at: http://papersubmission.scirp.org/

Or contact jbm@scirp.org 